\title{
HANKISS ÉS A RAJZFILMEK
}

\section{ELEMÉR HANKISS'S CONTRIBUTION TO HUNGARIAN ANIMATION}

\author{
Csortos Szabó Sándor \\ producer, Budapest Film Kft,. a Magyar Filmakadémia tagja, a kőszegi Felsőbbfokú Tanulmányok Intézete ösztöndíjasa \\ info@iask.hu
}

\begin{abstract}
ÖSSZEFOGLALÁS
Kevesen tudják, hogy Hankiss Elemér nélkül a magyar animáció története nem úgy alakult volna, ahogyan azt ma ismerjük. Hankiss 1968 és 1986 között a Pannónia Filmstúdió dramaturgja, később a stúdió Művészeti Tanácsának vezetője volt. Számtalan rajzfilm létrejöttét segítette, miközben ő maga is írt forgatókönyveket. Filmtervei közül egy megvalósult: az 1971-ben bemutatott, 11 perc hosszúságú Fény és árnyék. Ennek az alkotásnak Kovásznai György, korának fontos neoavantgarde rajzfilmese volt a rendezője. Hankiss hathatós támogatása kellett Rófusz Ferenc A légy című rajzfilmjéhez is - ha nem születik meg, ma nem lenne Oscar-díjas alkotása a magyar animációnak. Mindezek mellett Hankiss előbb az MTA Irodalomtudományi Intézetében, később a Szociológiai Intézetben dolgozott, és ugyanannyi energiát fordított a strukturalista elemzésekre, értékszociológiai kutatásokra, mint a rajzfilmekre. Ezek közül az előbbiek jól dokumentáltak és közismertek, az utóbbi, miszerint Hankiss tevőlegesen is részt vett a magyar animáció sikerében, ismeretlen maradt. Jelen tanulmányban, mely egy hosszabb mű kivonata, Hankiss Elemérnek ezt az elfeledett munkásságát szeretném bemutatni.
\end{abstract}

\section{ABSTRACT}

Few people are aware of the fact that Elemér Hankiss played a crucial role in the development of Hungarian animation. Hankiss was a dramaturg for the Pannonia Film Studio between 1968 and 1986, and later became the head of the Arts Council at the Studio. He contributed to the creation of numerous animated films, and also wrote some scripts. One of his projects Lights and Shadow was directed by a significant neo-avant-garde animator, György Kovásznai. Strong support from Hankiss was also needed for the animated short created by Ferenc Rófusz, The Fly. Had they failed, Hungarian animation would not have received an Oscar Award. At the same time, he worked at the Institute for Literary Studies and, later, the Institute for Sociology of the Hungarian Academy of Sciences (MTA), focusing as much effort on structuralist analyses and research in the sociology of values as on animated cartoons. While the former analyses are well-documented and well-known, the latter (Hankiss's active role in the success of Hungarian animation) has remained unknown. This study aims to explore this forgotten field in Elemér Hankiss's oeuvre.

Kulcsszavak: Hankiss, rajzfilm, animáció, Pannónia Rajzfilmstúdió, Rófusz Ferenc

Keywords: Hankiss, cartoon, animation, Pannonia Film Studio, Ferenc Rófusz 
Kevesen tudják, hogy Hankiss Elemér nélkül a magyar animáció története nem úgy alakult volna, ahogyan azt ma ismerjük. Hankissnak mint dramaturgnak és mint a Müvészeti Tanács vezetőjének elévülhetetlen érdemei voltak az animációs Oscar-dij megszerzésében is.

Hankisst egy véletlen találkozás vitte el a Pannónia Filmstúdióba. 1968 őszén Matolcsy Györggyel ${ }^{1}$ futott össze a XII. kerületi Maros és Csaba utca keresztezödésében, és a két férfi hosszan beszélgetett egymással. A diskurzus végén Matolcsy meghívta Hankisst a Pannóniába, egy filmvetítésre. Hankiss ebben az időben az MTA Irodalomtörténeti Intézetének volt fömunkatársa. Még nem a Társadalmi csapdák és a Diagnózisok ismert szerzöje, de már legépelte Shakespeare Hamletja-Kisérlet a tragédia társadalmi hatásának leirására címü doktori disszertációját (1967), és hamarosan befejezi az 1969-ben megjelent $A$ népdaltól az abszurd drámáig címü könyvének kéziratát.

Hankiss Elemérnek a Matolcsy által kedvelt rendező, Kovásznai György filmjeit vetítették le. Hankiss a vetítés után többoldalas levélben foglalta össze gondolatait a látottakról. Ezt az írást elküldte Matolcsy Györgynek, aki azonnal felkérte Hankisst, hogy legyen a stúdió munkatársa.

Hankiss örömmel kezdte meg a munkát, és igen hamar a Pannónia Filmstúdió Mủvészeti Tanácsának a tagja lett. Ennek a tanácsnak kellett kidolgoznia a stúdió közép- és hosszú távú művészeti terveit, és elözsűrizni, véleményezni a stúdióban készült forgatókönyveket, majd eldönteni, hogy azok közül melyikböl legyen film. A megvalósult filmröl újra a Mủvészeti Tanács döntött, hogy elfogadja-e a látott a formában, vagy változtatni kell rajta. Nevezzük nevén a dolgot: a Mủvészeti Tanács egyfajta kulturális cenzúra is volt.

Összességében nem volt jellemző a filmek betiltása a Pannóniára. Vagy azért, mert maguk a rendezők is érezték, hogy hol van az a határ, ameddig elmehetnek, vagy azért, mert a Müvészeti Tanács már a filmtervek szintjén megakadályozta a konfrontációt a hatalommal. Érdekes kettősség, hogy miközben Hankiss a Mủvészeti Tanács tagjaként maga is részt vett a hatalommal való konfrontáció elkerülésében, aközben tevőleges szerepe volt a határok „tágításában” is. A később Oscar-díjat nyert $A$ légy címü rajzfilmet ő védte meg a cenzúrától, és segített Rófusznak abban, hogy filmterve megvalósulhasson.

Hankiss a kreativitását nemcsak abban élte ki, hogy dramaturgként vagy a Müvészeti Tanács tagjaként véleményezett egy-egy filmtervet, hanem maga is készített filmforgatókönyvet. Nem tudni, hány filmterv füződött a nevéhez, a Magyar Nemzeti Filmarchívum csak két tervet őriz Hankisstól. Az egyik az 1970-ben született Játék, a másik az 1971. április 28-i keltezésủ A mai élet anatómiája címü

\footnotetext{
${ }^{1}$ Id. Matolcsy György, Matolcsy György jegybankelnök édesapja, animációsfilm-producer és filmtörténész, a Pannónia Filmstúdió egyik alapítója, stúdióvezetője volt.
} 
filmvázlat. Az előbbi, a Játék, megvalósult Fény és árnyék címmel, az utóbbi tervszinten maradt. A Játék keletkezésének pontos dátuma nem ismert, a Filmarchívumban 1970-es keltezéssel tartják nyilván. A végleges filmet, a Fény és árnyékot 1971 szeptemberében mutatták be, Kovásznai György rendezésében. ${ }^{2}$

Az archívumban lévő filmvázlat az első verziója a Fény és árnyéknak. A fellelhető anyaghoz Kovásznai György előszava is hozzá van tüzve. Kovásznai ezt írta Hankiss filmvázlata elé: „Hankiss Elemér forgatókönyve a müvészi köntösben elénk lépő tudományos ismeret igen izgalmas és érdekes teljesítménye, mely kiválóan alkalmasnak mutatkozik arra, hogy belöle animációs film készüljön. Ez a legmodernebb irodalomtudományi felfedezéseket élményközelbe hozható film-lehetőség a fogalom-jel-hangzás hármas egységére épül, tehát a leírható emberi beszéd játékos manifesztuma. Benne az elemi hang és ritmus öskezdeteitől a szótagok, szavak, mondatok lépcsőin a költészeti szép szférájáig emelkedünk, vagyis szem és fültanúivá lehetünk, amint egy fizikai (hang)anyag közléssé, értelemmé formálódik s ezen keresztül eljut az irodalmi esztétikumig."’3

A fenti idézetből látható, hogy Hankiss irodalomtudósként közelített az animációs filmhez mint müfajhoz. Ez nem véletlen, hiszen miközben Hankiss a Játék címü filmvázlatát - vagy annak későbbi verzióit - írta, aközben szervezte az 1970. április 9-11. között megtartott szegedi novellaelemző konferenciát (Hankiss, 1971a); kiadásra készítette elö a Formateremtő elvek a költöi alkotásban címü konferencia előadásait (Hankiss, 1971b); írt egy fontos tanulmányt az Akadémiai Kiadónak Az irodalomtudomány és a pszichológia címü kötetbe (Nyírö, 1970), és számos írást publikált a Kritikában és a Valóságban.

Hankiss Elemér filmterve 33 oldal, közel félórás rajzfilm lett volna belöle, ha megvalósul. Hankiss a könyvet „túlírta”, nem véletlen, hogy a megvalósult film csak 11 és fél perces lett. A filmterv dadaista versképekre emlékeztető szövegrészeket is tartalmaz ${ }^{4}$, pedig a Játék története egyszerủen elmesélhető: a betük-hangok születésén keresztül, a szavak születésén át, különböző mondatokat, idézettöredékeket láthatunk, hallhatunk. Egyfajta fordított dadaizmus: az értelmét vesztett, kontextus nélküli betűk, szótöredékek végül jelentést hordozó szavakká, mondattöredékekké állnak össze. A kiindulópont az „O” betű születése, melyet az „A”, „E”, „I” és „U” betűk követnek. A Hankiss által írt szövegben feltünik a megvalósult film címét adó Radnóti Miklós idézet is: „,s szép mint a fény és oly szép mint az árnyék..." (Radnóti, Levél a hitveshez). Ebből a verssorból származik a film címe: Fény és árnyék, és ez a verssor lesz a kiindulópontja is a kész filmnek, mely ezzel a felirattal kezdődik: „Ez a film egy mondat kibontakozása

\footnotetext{
${ }^{2}$ A Film Színház Muzsika 1971. szeptember 18-i cikke alapján datálva.

${ }^{3}$ Kovásznai György előszava Hankiss Elemér: Játék címü filmvázlatához. Magyar Nemzeti Filmarchívum. 1970.

${ }^{4}$ Hankiss Elemér: Játék. Kiadatlan forgatókönyv. Magyar Nemzeti Filmarchívum. 1970, 4, és 22.
} 
mozgó rajzban és emberi hangban a rendező és rajzoló önkénye szerint a primitív kezdettől a végső formáig. A mondat Radnóti Miklós egy sora: Szép mint a fény és oly szép mint az árnyék."

Ezután a felirat után a föcím jön, majd dobolásba simulva, a Hankiss által megírt betük-hangok: az „o”, ,a”, ,e”, ,i”, „u” betűk hallhatóak énekhangszerüen kiejtve. A látvány eközben egy formálódó emberi test, amely hol nőalak, hol amorf forma, hol talán férfialak, de akármi is, folyamatosan mozog, gyürödik, változik. Tehát Hankiss alapötlete, hogy a betük mint amorf testek mozogjanak és formálódjanak szavakká, a kész filmben emberi testté változtak át.

A film meghökkentette a kritikusokat, akik sematikus véleményeknél tovább nem jutottak. Sokáig, 1999-ig kellett várni arra, hogy megjelenjen az első olyan kritika, amely már kellő távolságból tekintett Hankiss és Kovásznai közös alkotására. Mezei Ottó a Kortársban így írt a filmről: „Az ízig-vérig modern értelmezésű kép-hang kapcsolatot, a magyar költészethez is kötődően, két filmjében realizálta Kovásznai, a Fény és árnyékban (1970) és a Hullámhosszokban (1971). Mindkettőben eredeti módon alkalmazza a század eleji »hangköltészet« és a korabeli szemiotika eredményeit, tanulságait - az érzelmi hatás csorbítása nélkül" (Mezei, 1999).

Kovásznai következő filmje, a kilenc és fél perces Hullámhosszok (1971) sok szempontból a Fény és árnyék folytatásának tekinthető. A film fócímében nincs megadva író, de Hankiss Elemér hatása letagadhatatlan.

A Hullámhosszok, a Fény és árnyékhoz hasonlóan, szöveges bevezetővel indul, ami megadja a film értelmezési keretét is: „Forgatjuk a rádió gombját $\mathrm{s}$ az éterből a legkülönfélébb hangbenyomások zúdulnak ránk. Ezek az impulzusok válogatás nélküliek és töredékesek, bennük mégis jellemzően zsong és lüktet a modern emberi világ. E film alkotói a festészeti látvány eszközeivel, szubjektív élményként követik a hullámhosszukat.” A film nézöjére valóban „a legkülönfélébb hangbenyomások zúdulnak", látszólag válogatás nélkül. Felhangzik a Kossuth Rádió szignáljának részlete, majd jazzimprovizáció, focimeccs-közvetítés, időjárás-jelentés, egy sor a Hamletből, klasszikus zene töredékei következnek. Külföldi rádióadók bemondóit halljuk, felcsendül a Szomorú vasárnap, majd egy ária, Zalatnay Cini slágere, Beatles és a Jó ebédhez szól a nóta után már csak szófoszlányok jönnek, majd egy versrészlet Tóth Árpád Lélektől lélekig címü költeményéböl. Ezután még több operett és sláger töredéke hangzik el, majd az utolsó másodpercekben, egy klasszikus zenei futam felett az alábbi szavak hallhatók különböző előadómüvészektől: ,,közvetítettünk”, , ,lélektöl”, ,,lélekig”.

Amíg a Fény és árnyékban a betűk, hangok töredékei állnak össze mondattá, addig a Hullámhosszokban már mondatok és zenei töredékek állnak össze hangkép-jel összhanggá. A Hullámhosszok a Fény és árnyék gondolatmenetét folytatja.

Kovásznai „újrahasznosította” a Fény és árnyék több grafikai elemét is a Hullámhosszokban. Amíg a Fény és árnyékban bizonyos képkockák fekete-fehérben 
láthatók, addig ugyanazok a kockák a Hullámhosszokban már színesek, vagyis Kovásznai a Fény és árnyék rajzait vette elő és színezte ki.

Miközben Kovásznai, Hankiss ötletéből kiindulva, a kép-jel-hang viszonyával kísérletezett az animációban, és rádióállomások hang-zörej-zene listáját állította össze hanganyagként, aközben John Cage a tengerentúlon, egy évvel korábban, 1970-ben mutatta be zenei performanszát, amelynek alapja több táskarádió gombjának ötletszerü csavargatása volt, előre felvett bemondó-szövegek random bejátszásával. Kovásznai ugyanarra épített, mint Cage: a rádió gombjának csavargatására, mivel a Hullámhosszok nézője ,,a rádió müsoráradatán közeledik s tölt el velük annyi időt, míg a rádióhallgató keresőgombja végigsiklik a hullámhosszokon" (Kovásznai, 2010, 204.).

Ugyanekkor, tehát a '70-es évek elején, a Balázs Béla Stúdióban szenvedélyes viták folynak a filmnyelv megújításáról. Bódy Gábor az egyik vezetője ennek a mühelymunkának, melynek lényege a filmnyelv szemiotikai, strukturalista megújítása, a film képi világának elemekre bontása, majd az elemek különféle, eddig ismeretlen kontextusú összeállítása. Kovásznai filmjében is ez történik, a rajzolt, festett, átfestett részletek, a melléjük rendelt hangokkal, effektekkel együtt új kontextust alkotnak. Mindezek alapján biztos vagyok abban, hogy Hankiss Elemér valamilyen formában részt vett a Hullámhosszok tervezésében is, ha másként nem, mint Kovásznai „múzsája” a Fény és árnyékon keresztül.

Hankiss Elemér hagyatékában még egy általa írt forgatókönyv volt fellelhetö, az 1986-os dátumot viselö Tom-Titi Tom-Tom, avagy egy cinke, aki nem akart énekelni címü rajzfilm terve. Különlegességét az adja, hogy Hankiss leírása szerint „A látványnak nagyobb szerepe van itt, mint általában a rajzfilmekben. Sokat repülünk, Pest és Buda felett, házak, parkok, hidak felett, a Duna felett, a Várdomb felett. [...] Azt hiszem, hogy a repülés közben látott mozgó városképek, tetők, házak animálásánál különösen tág tere nyílna a számítógépes animációnak." (Hankiss, 1986, 5.)

Meghökkentő, hogy Hankiss 1986-ban animációs filmforgatókönyvet írt, hiszen ekkor már az MTA Szociológiai Kutatóintézetének értékszociológiai és módszertani osztályát vezette. De még ennél is meglepőbb, hogy szemlátomást tudatosan tervezett számítógépes animációt a forgatókönyvébe akkor, amikor az első számítógépen készített animációs rövidfilm, a Vad dolgok (The Wild Things) Hankiss írása előtt csak két évvel, 1984-ben született meg. Az első egész estés számítógéppel készített animációs film, a Toy Story pedig majd kilenc évvel később, 1995-ben kerül moziba. Hogy mennyire megelőzte Hankiss ezzel a tervével a magyar valóságot, arra álljon itt egy rövid idézet a Pannónia Hirek címü üzemi lap 1987/3-as számából: „Elsősorban szeretnénk előrelépni a modern technológia bevezetése területén, azaz a számítógépes animáció irányába.”

Hankiss már három évvel korábban, 1984-ben elörelépett a számítógépes animáció irányába, legalábbis a tervek szintjén. 
Hankisst a Fény és árnyék bemutatásának idején, 1971-ben szoros ellenőrzés alá vonta az államhatalom. Ekkor került kiadásra két, általa szerkesztett konferenciakötet, és megjelent több írása is a Kritikában. Ezeknek tematikáját és az ott leírt, „a marxizmus gondolatvilágán kívülről származó elméleteket és müértelmező módszereket” nem tolerálta tovább a politika. „Értéknihilisták voltunk. Mi nem tudtuk, mit jelent az, de annak neveztek minket" - mondja Hankiss Elemér egy interjúban (Zombory, 2015). Mindez nem akadályozta Hankisst a Pannónia Filmstúdióbeli munkájában. Ugyan az elkövetkező évekből nem maradt adat a tevékenységére vonatkozóan, de a visszaemlékezésekből kiderül, hogy 1981-ben ő az, aki Rófusz Ferenc $A$ légy címü filmtervét megvédi a Müvészeti Tanács előtt. A légy ötletének alapját a Pink Floyd együttes Ummagumma címü lemeze adta, amely - sok más zörej és effekt mellett - légyzümmögéssel is zörejezve volt. Ez tetszett meg Rófusznak: ,ahogy hallgattam ezt a zenét, előttem lepergett az egész film. És akkor... megrajzoltam egy storyboardot, csináltam egy grafikát, hogy milyen stílusban szeretném, egy nagy rajztáblára föl volt kasírozva... és leadtam a Mủvészeti Tanácsra..., és hát akkoriban mindig attól féltek, hogy mi az üzenet egy ilyen egyedi filmben, mert azért... az egyedi filmekben mindig valami el volt dugva, valamit üzentek... mindig volt valami kis trükk a dologban. És mindig gyanakodtak, és hát mindenki le akarta magát védeni, hogy nehogy ebből valami probléma legyen, és emlékszem, hogy ott az első kérdés az volt, hogy ki a légy, és ki az, aki kergeti?"5

Ez az idézet jól illusztrálja a korszak paranoiáját, amely a Mủvészeti Tanácsban is megjelent. Miközben a tanács próbálta megfejteni a filmtervben levő politikai üzenetet, Rófusz szerint Hankiss a tanácstagok figyelmét valami másra akarta felhívni: ,ez volt az első háttér-animációs filmterv, mert a világon nem csináltak háttér-animációs filmet... és emlékszem, akkor kezdett az Elemér ezzel a témával foglalkozni, és kardoskodott a Matolcsy felé is, hogy hát figyelj, még nem csináltak háttér-animációs filmet..."

Hankiss tehát a politikai vetületről szakmai síkra próbálta terelni az ügyet: „...ő végig állította, hogy... ilyen film még nem készült, és ez egy annyira más látásmód... nagyon ügyesen ő nem a sztoriról beszélt állandóan. Szóval, bárki rátért arra, hogy de igen, de ki a légy..., ő akkor mindig a szubjektív kamerát magyarázta, és hogy ez egy egész más látásmód, és... hogy mennyire másképp mutatjuk be az egész világot..., ő képes volt erről akár egy órán keresztül is úgy beszélni, hogy egy szót nem beszélt arról, hogy mi az üzenet." Filmtörténeti szempontból Hankissnak igaza volt, 1981-ig egyetlen háttér-animációs filmet sem gyártottak, még a nagy amerikai stúdiók sem.

Tehát a magyar animáció első és eddig egyetlen Oscar-díja az alkotó Rófusz Ferencen kívül Hankiss Elemérnek is köszönhetö.

\footnotetext{
${ }^{5}$ Idézet a Rófusz Ferenccel készített interjúból.
} 


\section{IRODALOM}

Hankiss E. (1970): Játék. Kiadatlan forgatókönyv. Magyar Nemzeti Filmarchívum

Hankiss E. (szerk.) (1971a): A novellaelemzés új módszerei. Szegedi novellaelemző konferencia, 1970. ápr. 9-11. Budapest: Akadémiai Kiadó

Hankiss E. (szerk.) (1971b): Formateremtő elvek a költői alkotásban. Vitaülés 1968. november 14-15. MTA Stilisztikai és Verstani Munkabizottsága. Előadások és hozzászólások. Budapest: Akadémiai Kiadó

Hankiss E. (1986): Tom-Titi Tom-Tom, avagy egy cinke, aki nem akart énekelni. Kiadatlan forgatókönyv.

Horányi Ö. - Matolcsy Gy. (szerk.) (1975): Tanulmányok a magyar animációs filmröl. Budapest: Magyar Filmtudományi Intézet és Filmarchívum, http://socio.hu/uploads/files/2015_1/zombory_hankiss.pdf(Letöltés: 2018. 03. 07.)

Interjú Rófusz Ferenccel (2018): K. Csortos Szabó Sándor. Az eredeti hangfájl az iASK Hankiss Elemér Intézetben

Irodalom- és művészetkritikánk néhány kérdése: Az MSZMP KB mellett működő Kultúrpolitikai Munkaközösség állásfoglalása. Társadalmi Szemle, 27, 10, 26-39.

Iványi-Bitter B. (2010): Kovásznai. Budapest: Vince Kiadó

Kovásznai Gy. (1971): Hullámhosszok. Színes rajzfilm. https://www.youtube.com/watch?v=7yHRVngb4YU (Letöltés: 2018. 03. 09.)

Kovásznai Gy. (2010): Mentségeim. In: Iványi-Bitter B.: Kovásznai. Budapest: Vince Kiadó

Kovásznai Gy. - Hankiss E. (1970): Fény és árnyék. Színes rajzfilm. http://kovasznai.org/post. php?p=623 (Letöltés: 2018. 03. 09.)

Mezei O. (1999): Történelmi határeset - Kovásznai György munkásságáról. Kortárs. 44, szeptember 9. http://home.hu.inter.net/kortars/9909/mezei.htm

Nyírő L. (szerk.) (1970): Az irodalomtudomány és a pszichológia. Tanulmányok a XX. századi irodalomtudomány irányzatairól. Budapest: Akadémiai Kiadó

Pannónia Hírek. A Pannónia Film Vállalat lapja (1987): 3, április 2.

Radnóti M. (1996): Levél a hitveshez. In: Radnóti Miklós: Eröltetett menet - válogatott versek. Budapest: Interpopulart Könyvkiadó

Zombory M. (2015): Szociológián innen és túl. Zombory Máté interjúja Hankiss Elemérrel. In: http://socio.hu/uploads/files/2015_1/zombory_hankiss.pdf(Letöltve: 2018. 03. 07.) 